\title{
How do Specific Conditions Shape Values of Undergraduate Early Childhood Education Students in Slovenia?
}

\author{
Marta Licardo* \\ marta.licardo@um.si \\ https://orcid.org/0000-0002-5858-8527
}

\author{
https://doi.org/10.31192/np.19.3.4 \\ UDK / UDC: 17.022 .1 \\ 373.2-057.875(497.4) \\ Izvorni znanstveni rad / \\ Original scientific paper \\ Primljeno / Received: \\ 13. svibnja 2021. / May 13, 2021 \\ Prihvaćeno / Accepted: \\ 8. srpnja 2021. / Jul 8, 2021
}

The purpose of the study is to examine the early childhood education students' values and what are the differences in the students' values in specific conditions related to social environment. The values of undergraduate students who study early childhood education are very important for professional development and practice. The purpose of this study is to determine, if their values change during their study programme; which values are more important to the students; and what are the differences in the students' values in terms of the type of study (full time/part time), years of study, age, work experience and work status. Results indicate that employed students have higher scores on other-centred values than unemployed students, older students express more others-centred values than younger students, while in self-centred values there are no age differences. Students who have more work experience express more others-centred values and students who study longer express more others-centred values than fresh students, while in self-centred values differences by years of study do not occur. These results reveal important changes in the hierarchy of values related to measured variables and interplay between various conditions.

Key words: age, ecological conditions, higher education, students of early childhood education, values.

\footnotetext{
* Marta Licardo, PhD, Assist. Prof., Faculty of Education, University of Maribor; Address: Koroška cesta 160, 2000 Maribor, Slovenia.
} 


\section{Introduction}

To research the values of early childhood education students is important because beliefs and values are at the core of teaching. Teachers often act more on the basis of beliefs and values than on their knowledge. ${ }^{1}$ Students might enter education programmes with a preconception of early childhood education teacher role identity and values based on memories of previous teachers, former education experience and personal events and value systems. ${ }^{2}$ These preconceptions should be rebuilt during their education and practice because values constitute a very important component of a student's understanding of children and teaching. ${ }^{3}$

The research of the values of early childhood education students is important for a number of reasons:

a) Values have an influence on the grasp of knowledge and its interpretation during the study programme. There are several models and theories that describe teacher development ${ }^{4}$, which suggests that prior beliefs and values play a critical role in determining their grasp of knowledge from teacher education programs and how they will interpret this knowledge. The process is working in both ways. Study process and other professional training shapes the values. ${ }^{5}$

${ }^{1}$ Dona M. KAGAN, Implication of research on teacher belief, Educational Psychologist, 27 (1992) 1, 75; Brigit D. WAGNER, Lucia FRENCH, Motivation, Work Satisfaction, and Teacher Change Among Early Childhood Teachers, Journal of Research in Childhood Education, 24 (2010) 2, 152, 153, 154.

2 Marion, JONES, Reconciling personal and professional values and beliefs with reality of teaching: findings from an evaluative case study of 10 newly qualified teachers during their year of induction, Teacher development, 7 (2003) 3, 386; Valentina F. PETROVA, Religious identity and value systems of future preschool teachers, International Journal of Environmental and Science Education, 11 (2016) 6, 1117-1118, 1121.

${ }^{3}$ Tricia GIOVACCO-JOHNSON, Applied ethics as foundation in early childhood teacher education: exploring the connections and possibilities, Early Childhood Education Journal, 38 (2011) 449-452.

${ }^{4}$ Kevin RYAN, The induction of new teachers, Bloomington, Phi Delta Kappa, 1986, 8-12, 1618, 31-38; Douwe BEIJAARD, Paulien C. MEIJER, Nico VERLOOP, Reconsidering research on teachers' professional identity, Teaching and Teacher Education, 20 (2004) 107-109, 113-126; Dona M. KAGAN, Professional growth among pre-service and beginning teachers, Review of Educational Research, 62 (1992) 2, 129-169; Sandra HOLLINGSWORTH, Prior beliefs and cognitive change in learning to teach, American Educational Research Journal, 26 (1989) 2, 160-189; Dana N. FICHTMAN, Laurie WESTCOTT, Creating opportunities for reflection in the early childhood teachers, Journal of Early Childhood Teacher Education, 18 (1997) 1, 31-45; Jeniffer E. ALDRICH, Kelli R. THOMAS, Evaluating constructivist beliefs of teacher candidates, Journal of Early Childhood Teacher Education, 25 (2005) 4, 339-347; Vivienne COLLINSON, Sources of teachers' values and attitudes, Teacher Development, 16 (2012) 3, 321-344; Susan L. RECCHIA, Lisa M. BECK, Reflective practice as »enrichment«: How new childhood teachers enact preservice values in their clasrooms, Journal of Early Childhood Teacher Education, 35 (2014) 3, 203-205.

${ }^{5}$ Linda DARLING-HAMMOND, Ruth CHUNG, Fred FRELOW, Variation in teacher preparation - how well do different pathways prepare teachers to teach?, Journal of Teacher Education, 
Seemingly, research ${ }^{6}$ about students who graduate from postsecondary preschool teacher preparation programmes tend to maintain the beliefs that they had when they started their education. These strongly held beliefs and values are formed over a very long period of time and are highly resistant to change. But as they become older and study longer, early childhood teacher educators may be more successful in influencing desired beliefs and values. ${ }^{7}$ During education there is an opportunity to rebuild the hierarchy or other specific traits of students' values. ${ }^{8}$

b) Teachers, as any other individual, often act more on the basis of their beliefs and values than their knowledge. ${ }^{9}$ Because of the many and various opportunities in concrete settings it seems values are not just something that students or teachers have or have not, but they are something that they do. Although overall process should be researched in greater depth, social interactions and actor-situation transactions are closely related to the quality and quantity of engagement in environment, which might be reflected in expressed values and beliefs..$^{10}$

\section{c) Various individual and ecological conditions are related to values}

Individual changes arise in concrete settings in particular social conditions and circumstances ${ }^{11}$ as is suggested in discussion about holistic and individualistic explanations of social actions and changes in beliefs and values. ${ }^{12}$ For example, employment status might be important dimension regarding values because those students who are employed have more explicit and everyday opportunities to exercise higher degrees of professional behaviour within the context in which they work. Employment is an important condition by which

53 (2002) 4, 286-302.

${ }^{6}$ Dan C. LORTIE, Schoolteacher: a sociological study, Chicago, University of Chicago Press, 2002, 25-82, 162-214.

7 Marry B. McMULLEN, Kazim ALAT, Education matters in the nurturing of the beliefs of preschool caregivers and teachers, Early Childhood research and Practice, 4 (2002) 2, 1-14; Marry B. McMULLEN, Effects of early childhood academic and professional experience on self-perceptions and beliefs about developmentally appropriate practices, Journal of Early Childhood Teacher Education, 18 (1997) 3, 55-68.

${ }^{8}$ Fred A. KORTHAGEN, In search of the essence of a good teacher: towards a more holistic approach in teacher education, Teaching and Teacher Education, 20 (2004) 1, 77-97; Collinson, Sources of teachers' values and attitudes..., 338.

9 Kagan, Implication of research on teacher belief..., 65-67; Jones, Reconciling personal..., 386387, 396-398.

${ }^{10}$ Jan NESPOR, The role of beliefs in the practice of teaching. Journal of Curriculum Studies, 19 (1987) 317-328; Gert BIESTA, Mark PRIESTLEY, Sarah ROBINSON, The role of beliefs in teacher agency, Teachers and Teaching, 21 (2015) 6, 624-640.

${ }^{11}$ Sally A. BROWN, Donald, McINTYRE, Making sense of teaching: Developing teachers and teaching, 1993, Buckingham Open University Press, 21-49, 69-91, 107-120; Michelle M. BUEHL, Jori S. BECK, The relationship between teachers' beliefs and teachers' practices, In: Helenrose FIVES, Michelle G. GILL (Eds.), International Handbook of Research on Teachers' beliefs, New York, Routledge, 2015, 66-84.

${ }^{12}$ Biesta et al., The role of beliefs..., 625. 
values might be shaped, because values and beliefs are influenced by teachers' responses to social interactions within working environment (with children, parents, other teachers, management staff, local community) and as such, values can be understood as an emergent phenomenon of actor-situation transaction. Studies about complex interactions between beliefs and values held by individual teachers show they are often biased by the working environment. ${ }^{13}$

\section{d) Teachers serve as role models for character, morality, social and emotional skills}

Early childhood education teachers play a key role in supporting children's moral development. ${ }^{14}$ Research of teacher moral reasoning has shown that postconventional moral reasoning is required for teachers who serve as role models of morality and values in educational institutions..$^{15}$ The teacher's level of moral reasoning and values affects the children's perception of values and moral atmosphere in the group (i.e. classroom). Teachers with higher moral reasoning are more likely to motivate the students' learning and social development than a teacher with lower moral reasoning. ${ }^{16}$

Teachers in early childhood education with stronger positive values and belief appraisals are more likely to propose and adopt the use of different kinds of positive early childhood intervention practices, ${ }^{17}$ they are more likely to be a role model in terms of morality and behaviour, ${ }^{18}$ they will also teach children desirable social and emotional skills and values. ${ }^{19}$ In addition, teachers who possess strong values will be more likely to take responsibility for personal and organisational learning, and they will use early childhood intervention

${ }^{13}$ James CALDERHEAD, Susan B. SHORROCK, Understanding teacher education: case studies in the professional development of beginning teachers, London, The Falmer Press, 1997, 13-20; Buehl, Beck, The relationship..., 69-80.

${ }^{14}$ Gunilla DAHLBERG, Peter MOSS, Ethics and politics in early childhood education, New York, Routledge Falmer, 2005, 86-97; Ingibjorg SIGURDARDOTTIR, Pia WILLIAMS, Johanna EINARSDOTTIR, Preschool teachers communicating values to children, International Journal of Early Years Education, 27 (2019) 2, 172, 173.

${ }^{15}$ Fon-Yean CHANG, School teachers' moral reasoning, In: James R. REST, Darcia NARVAEZ (Eds.), Moral development in the professions. Psychology and applied ethics, New Jersey, Erlbaum, 1994, 71-83.

${ }^{16}$ Landon E. BEYER, The moral contours of teacher education, Journal of teacher education, 48 (1997) 245-250.

${ }^{17}$ Carol M. TRIVETTE et al., Research synthesis of studies investigating the relationships between practitioner beliefs and adoption of early childhood intervention practices, Practical Evaluation Reports, 4 (2012) 1, 1-19.

${ }^{18}$ Ayla OKTAY, Oya RAMAZAN, Ahmet SAKIN, The relationship between teachers' professional ethical behavior perceptions, moral judgment levels and attitudes to teaching, Gifted Education International, 26 (2010) 1, 6-14.

${ }^{19}$ Melek DEMIREL, Demek OZMAT, Imgehan O. ELGUN, Primary school teachers' perceptions about character education, Educational Research and Review, 11 (2016) 27, 1622-1633. 
programme practices in ways that intended and expected. ${ }^{20}$ The paradigm in education (especially in early childhood education) is to promote equality and fairness, ethical decision making, sustainability and protecting the children's rights. ${ }^{21}$ These are the reasons why it is important to promote positive values in study programmes for early childhood education teachers if we wish to educate ethical professionals who will follow positive beliefs, core values and principles that define appropriate behaviour and decision making and will be more resilient to less positive values in their working environment and it is also a strong argument to research values of early childhood education teachers more in depth.

The purpose of the research is to focus on some of individual and specific social conditions mentioned above. More precisely, to analyse differences in values between students by age, status (employed/student), work experience and years of study, because there is little evidence of research based on various conditions related to values in the population of undergraduate early childhood education students.

\section{Method}

\subsection{Participants}

The research sample among students of early childhood education in Slovenia consisted of 197 students, 97,5\% $(N=192)$ were females and 2,5\% $(N=$ $5)$ were males. Half of students in the sample $(50,3 \%, N=95)$ were 18 to 23 years old, $18,8 \%(N=37)$ were 24 to 29 years old, $16,2 \%(N=32)$ were 30 to 35 years old, and $14,7 \%(N=29)$ were more than 36 years old. Students of early childhood education in Slovenia study at three different Faculties of Education from three universities. A total of $42,6 \%(N=84)$ of the students in the sample were enrolled at the University of Maribor, $32,5 \%(N=64)$ at the University of Ljubljana and $24,9 \%(N=49)$ study at the University of Primorska. The early childhood education study programmes are similar in all three universities. A total of $35 \%(N=69)$ of individuals were in the first year of study, $27,4 \%(N=54)$ were enrolled in the second year, 32,5\% $(N=64)$ were in the third year and $5,1 \%$ $(N=10)$ were in their last year of study. Half of them $(49,7 \%, N=95)$ are just studying (student status), while 50,3\% ( $\mathrm{N}=98)$ were studying and are employed (employed status). Average years of work experience is 2,41 years $(\mathrm{SD}=1,37)$, $33,5 \%(N=63)$ have no work experience.

\footnotetext{
${ }^{20}$ Carl J. DUNST, Carol M. TRIVETTE, Using research evidence to inform and evaluate early childhood intervention practices, Topics in Early Childhood, Sp. Ed., 29 (2011) 40-44.

${ }^{21}$ Lili-Ann WOLF, Tuula H. SKARSTEIN, Frode SKARSTEIN, The mission of ECE in the anthropocene, Education Sciences, 10 (2020) 27, 1-21.
} 


\subsection{Instrumentation}

The instrument for measuring the values was made for the purpose of this study. The instrument is partially based on The Human Values Scale. ${ }^{22} \mathrm{We}$ have followed the general ideas from the mentioned scale, adapted the content of particular variables to the context which is relevant for the students (e.g. adapted part of variable is in italics; Sincerity is important for me. At my work as a teacher, I wish to have sincere relationships; It's important for me to discover new knowledge and get new skill as preschool teacher), removed variables which were not relevant and changed the scale for responses from six to five items. The questionnaire was initially validated by exploratory factor analysis to analyse the factor structure, direct oblimin rotation was used. The final version of the variables with factor loadings and interpretation of the factory analysis is available online. ${ }^{23}$ The instrument is tailored for students of education (it may be used for students of early childhood education or other students of educational studies) and has two dimensions: a) others-centred values, and b) self-centred values. We have used a 5-item Likert scale (1 - not like me at all, 2 - not like me, 3 - somewhat like me, 4 - like me, 5 - very much like me). The variables that measure others-centred values are related to care for others, care for equality in education, to promote righteousness, collaboration, to have good relationships with others, to teach children honesty, and responsibility. The variables for self-centred values measure personal values of money and wealth, achievements, adventures, fun and rewards, others (parents and children) respect of the teacher, and others (education institution, parents) acknowledgement of the teacher's work. Our questionnaire of student values is tailored for students of education because we wanted to measure specific variables which relate to work with children and work environment in education institutions while also basing our study on universal values.

\subsection{Data Collection and Analysis}

The data were collected with an e-version of the questionnaire in year 2019. It is convenience random sample among the population of early childhood education students in three Faculties of Education in Slovenia. Link to the questionnaire was sent only to undergraduate students of early childhood education by students' group e-mails and personal emails. The students' responses

\footnotetext{
${ }^{22}$ European Social Survey, ESS Round 6 Source Questionnaire, London, Centre for Comparative Social Surveys, City University London, 2012; Shalom H. SCHWARTZ et al., Personality processes and individual differences: Refining the theory of basic individual values, Journal of Personality and Social Psychology, 103 (2012) 4, 663-688.

${ }^{23}$ Marta LICARDO, The final version of the variables with factor loadings (Table and interpretation), 2021, DOI. 10.6084/m9.figshare.14564331.
} 
are anonymous. To analyse the differences by age and years of study, years of work experience one-way ANOVA was used. To analyse the differences by student's status, a T-test test was used. The homogeneity of variances as assessed in all variables with Levene test $(p<0,005)$ and Welch test $(p<0,005)$ is not met. We have decided to run analysis of variance (one-way ANOVA) anyway and calculated Games Howell post hoc test or LSD post hoc test (depends on the results of Levene test) and we also calculated the effect sizes and the retest with non-parametric Kruskal Wallis test, because in few variables equality of variances was not met.

\section{Results}

In this chapter we present the descriptive statistics for both group of values, differences by age, years of study, by students' status and by years of work experience.

\subsection{Descriptive statistics for other-centred and self-centred values}

Table 2 Descriptive statistics for other-centred and self-centred values

\begin{tabular}{|c|c|c|c|c|c|}
\hline Other-centred values & $\mathbf{N}$ & Min & Max & M & SD \\
\hline $\begin{array}{l}\text { In working with children, it is very important to deal } \\
\text { equally with everyone. I believe in life everyone should have } \\
\text { equal opportunities. }\end{array}$ & 194 & 4 & 5 & 4,66 & 0,47 \\
\hline $\begin{array}{l}\text { I think it is important to teach children how to be honest } \\
\text { and responsible. }\end{array}$ & 197 & 3 & 5 & 4,63 & 0,50 \\
\hline $\begin{array}{l}\text { To care for those who need help is important to me. As a } \\
\text { ECE teacher I should teach children about that. }\end{array}$ & 197 & 3 & 5 & 4,42 & 0,64 \\
\hline To promote righteousness in society is important to me. & 197 & 2 & 5 & 4,38 & 0,68 \\
\hline $\begin{array}{l}\text { For me, it is important to take care of the people around } \\
\text { me. I want to care for their well-being. }\end{array}$ & 197 & 2 & 5 & 4,34 & 0,74 \\
\hline I think it is important to feel devoted to the group. & 197 & 2 & 5 & 4,30 & 0,70 \\
\hline $\begin{array}{l}\text { For me, it is important to listen to people who are different } \\
\text { from me. Even if I disagree, I still want to understand them. }\end{array}$ & 197 & 3 & 5 & 4,28 & 0,64 \\
\hline $\begin{array}{l}\text { To have good relationships with school mates or co- } \\
\text { workers is important to me. I want to devote myself to } \\
\text { people close to me at work. }\end{array}$ & 197 & 2 & 5 & 4,25 & 0,70 \\
\hline $\begin{array}{l}\text { For a ECE teacher it is important to collaborate with the } \\
\text { local community. }\end{array}$ & 196 & 3 & 5 & 3,95 & 0,65 \\
\hline
\end{tabular}




\begin{tabular}{|l|c|c|c|c|c|}
\hline Self-centred values & \multicolumn{5}{|c|}{} \\
\hline $\begin{array}{l}\text { To get respect of others is important to me. I want parents } \\
\text { and children to consider what I say. }\end{array}$ & 197 & 2 & 5 & 4,15 & 0,77 \\
\hline To be active in sport is important to me. & 197 & 2 & 5 & 3,82 & 0,94 \\
\hline To experience many new things is important to me. & 197 & 2 & 5 & 3,77 & 0,80 \\
\hline Job promotions are important to me. & 197 & 2 & 5 & 3,70 & 0,86 \\
\hline $\begin{array}{l}\text { As a student it is important to show my abilities. I want } \\
\text { others to see and recognise my work. }\end{array}$ & 197 & 2 & 5 & 3,63 & 0,85 \\
\hline $\begin{array}{l}\text { To be very successful is (very) important to me. I hope } \\
\text { others will recognise my achievements. }\end{array}$ & 197 & 2 & 5 & 3,48 & 0,82 \\
\hline Rewarding is important to me. & 197 & 1 & 5 & 3,15 & 0,88 \\
\hline $\begin{array}{l}\text { I seek adventures and I like to risk. I wish to have an } \\
\text { exciting life. }\end{array}$ & 197 & 1 & 5 & 3,04 & 0,76 \\
\hline $\begin{array}{l}\text { For me, it is important to be rich. I want to have a lot of } \\
\text { money and expensive things. }\end{array}$ & 197 & 1 & 5 & 2,04 & 0,72 \\
\hline
\end{tabular}

The results indicate that among other-centred values the mean scores are in range 3,94 to 4,66 . The highest mean score is for the value about equality and equal opportunities when working with children $(M=4,66$; $S D=0,47)$, to teach children how to be honest and responsible $(M=4,36 ; \mathrm{SD}=0,50)$, to care for those, who need help and to teach children about that issue $(M=4,42$; SD $=0,64)$. The lowest mean score is related to value about collaboration with the local community $(\mathrm{M}=3,95 ; \mathrm{SD}=0,65)$.

Among self-centred values the mean scores are in range 2,04 to 4,15. Most of the means are slightly lower than in other-centred values. The highest mean score in self-centred values is about importance of getting the respect of others (parents and children) $(M=4,15 ; S D=0,77)$, to be active in sport $(M=3,82$; $\mathrm{SD}=0,94)$, to experience many new things $(\mathrm{M}=3,82$; $\mathrm{SD}=0,94)$ and to get a job promotion $(M=3,70 ; S D=0,86)$. The lowest mean value is for seeking adventures, exciting life, and taking risks $(M=3,04 ; S D=0,76)$ and to be rich, have a lot of money and expensive things $(M=2,04 ; \mathrm{SD}=0,72)$. 


\subsection{Differences in Values by Age, Status, Work Experience and Years of Study}

Table 3 Differences in values by student's age and years of study

\begin{tabular}{|c|c|c|c|c|c|c|c|c|}
\hline \multirow[t]{2}{*}{ Values } & \multirow[t]{2}{*}{ Age } & 苞 & $\sum_{\Sigma}^{\Xi}$ & 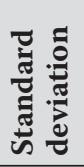 & 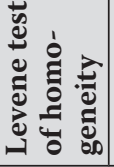 & 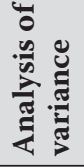 & 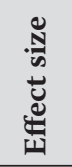 & 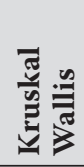 \\
\hline & & $N$ & $\mathbf{M}$ & SD & $\mathbf{F}$ & $\mathbf{F}$ & & \\
\hline \multirow{4}{*}{$\begin{array}{l}\text { Others- } \\
\text { centred } \\
\text { values }\end{array}$} & $18-23$ & 95 & $-0,12$ & 0,82 & \multirow{4}{*}{$4,51^{*}$} & \multirow{4}{*}{3,76} & \multirow{4}{*}{0,24} & \multirow{4}{*}{$\begin{array}{c}12,94 \\
* * * * * *\end{array}$} \\
\hline & $24-29$ & 37 & $-0,24$ & 1,29 & & & & \\
\hline & $30-35$ & 32 & 0,43 & 0,96 & & & & \\
\hline & 36 and more & 29 & 0,22 & 1,03 & & & & \\
\hline \multirow{5}{*}{$\begin{array}{l}\text { Self-centred } \\
\text { values }\end{array}$} & $18-23$ & 95 & 0,02 & 0,93 & \multirow{4}{*}{1,12} & \multirow{4}{*}{0,15} & \multirow{4}{*}{0,05} & \multirow{4}{*}{0,38} \\
\hline & 24-29 & 37 & $-0,04$ & 1,15 & & & & \\
\hline & $30-35$ & 32 & 0,06 & 1,08 & & & & \\
\hline & 36 and more & 29 & $-0,09$ & 0,98 & & & & \\
\hline & Years of study & & & & & & & \\
\hline \multirow{4}{*}{$\begin{array}{l}\text { Others- } \\
\text { centred } \\
\text { values }\end{array}$} & $1^{\text {st }}$ year & 67 & 0,05 & 0,88 & \multirow{4}{*}{2,68} & \multirow{4}{*}{$3,19^{*}$} & \multirow{4}{*}{0,22} & \multirow{4}{*}{11,06} \\
\hline & $2^{\text {nd }}$ year & 53 & $-0,27$ & 0,94 & & & & \\
\hline & $3^{\text {rd }}$ year & 63 & 0,07 & 1,13 & & & & \\
\hline & $4^{\text {th }}$ year & 10 & 0,70 & 0,78 & & & & \\
\hline \multirow{4}{*}{$\begin{array}{l}\text { Self-centred } \\
\text { values }\end{array}$} & $1^{\text {st }}$ year & 67 & $-0,02$ & 0,93 & \multirow{4}{*}{0,69} & \multirow{4}{*}{0,12} & \multirow{4}{*}{0,04} & \multirow{4}{*}{0,05} \\
\hline & $2^{\text {nd }}$ year & 53 & $-0,04$ & 0,93 & & & & \\
\hline & $3^{\text {rd }}$ year & 63 & 0,06 & 1,15 & & & & \\
\hline & $4^{\text {th }}$ year & 10 & 0,01 & 0,98 & & & & \\
\hline
\end{tabular}

Results of ANOVA which shows differences by age indicate the CWWS score is statistically significantly different between age groups for other-centred values $\mathrm{F}(3,189)=3,76, \mathrm{p}=0,012$, The effect size is large $=0,24)$ (Kirk, 1996). The same result is confirmed with Kruskal Wallis test $(\mathrm{H}(3)=12,94$, $\mathrm{p}$ $=0,005)$, CWWS score increases from age group 24-29 years $(\mathrm{M}=-0,24, \mathrm{SD}=$ $1,29)$, to age group $18-23$ years $(M=-0,12, S D=0,82)$ to age group 36 and more years $(M=0,22 ; S D=1,03)$ and to the age group 30-35 years $(M=0,43 ; S D=$ $0,96)$, Games-Howell post hoc test reveal that mean values increase is statistically significant from age group $18-23$ years to age group $30-35$ years $(0,55,95 \%$ $\mathrm{CI}[0,04,1,05], \mathrm{p}=0,02)$, However, regarding differences in self-centred values by age, we can conclude there are no statistically significant differences and the effect size is small $\left(\omega^{2}=0,05\right)$.

Results of ANOVA which shows differences by years of study indicate the CWWS score is statistically significantly different between age groups for 
other-centred values $F(3,189)=3,19, \mathrm{p}=0,02,=0,22$. Again, the effect size is large. CWWS score increases from $2^{\text {nd }}$ year students $(M=-0,27 ; S D=0,94)$, to $1^{\text {st }}$ year students $(M=0,05 ; S D=0,88)$ to $3^{\text {rd }}$ year students $(M=0,07 ; S D=1,13)$ and to $4^{\text {th }}$ year students $(M=0,70 ; S D=0,78)$.

LSD post hoc test reveal that means values increase and are statistically significant from $1^{\text {st }}$ year students to $4^{\text {th }}$ year students $(0,64,95 \%$ CI $[-0,01,1,30]$, $\mathrm{p}=0,05)$ and from $2^{\text {nd }}$ year students to $4^{\text {th }}$ year students $(0,97,95 \% \mathrm{CI}[0,30$, $1,63], p=0,005)$. There is also tendency to statistically significant increase of the means values between $2^{\text {nd }}$ year students and $3^{\text {rd }}$ year students $(0,34,95 \% \mathrm{CI}$ $[0,02,0,70], \mathrm{p}=0,06)$, between $1^{\text {st }}$ and $2^{\text {nd }}$ years students $(0,32,95 \% \mathrm{CI}[-0,67$, $0,03], \mathrm{p}=0,07)$ and between $3^{\text {rd }}$ and $4^{\text {th }}$ year students $(0,62,95 \%$ CI $[-0,03,1,28]$, $\mathrm{p}=0,06)$. Regarding differences in Self-centred values by age we can conclude there are no statistically significant differences, and the effect size is small $\left(\omega^{2}\right.$ $=0,04)$.

Table 4 Differences in values by student's employment status

\begin{tabular}{|c|c|c|c|c|c|c|c|}
\hline & & Numerus & Mean & $\begin{array}{l}\text { Standard } \\
\text { deviation }\end{array}$ & $\begin{array}{l}\text { Levene test } \\
\text { of homo- } \\
\text { geneity }\end{array}$ & \multicolumn{2}{|c|}{ T test } \\
\hline Values & status & $N$ & M & SD & $\mathrm{F}$ & $\begin{array}{c}\mathrm{t} \\
(d f)\end{array}$ & $\mathrm{P}$ \\
\hline \multirow{2}{*}{$\begin{array}{l}\text { Others-centred } \\
\text { values }\end{array}$} & student & 95 & $-0,17$ & 0,85 & \multirow{2}{*}{$5,11^{*}$} & $-2,29$ & \multirow{2}{*}{0,02} \\
\hline & employed & 98 & 0,16 & 1,11 & & $(181,3)$ & \\
\hline \multirow{2}{*}{ Self-centred values } & student & 95 & 0,05 & 0,93 & \multirow{2}{*}{2,12} & 0,74 & \multirow{2}{*}{0,46} \\
\hline & employed & 98 & $-0,05$ & 1,07 & & (191) & \\
\hline
\end{tabular}

Others-centred values differ statistically significant when compared with the students' status. Due to the assumption of homogeneity of variances being violated, as assessed by Levene's test $(p=0,03)$ for other-centred values, the $t$-test results for equal variances not assumed were used. T-test indicate that employed students express higher others-centred values $(t(181,3)=-2,20$, $p=0,02)$ than unemployed students. Significant differences do not occur in self-centred values ( $\mathrm{t}(191)=0,74, p=0,46)$. However, the mean value for selfcentred values of employed students is lower $(M=-0,05, S D=1,07)$ than the mean value of full-time students $(\mathrm{M}=0,05, \mathrm{SD}=0,93)$. 
Table 5 Differences in values by years of work experience

\begin{tabular}{|c|c|c|c|c|c|c|c|}
\hline \multirow[t]{2}{*}{ Values } & \multirow[t]{2}{*}{ Work experience } & 苞 & 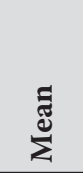 & 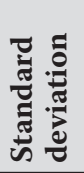 & 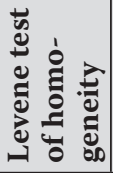 & 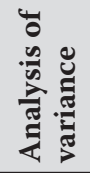 & 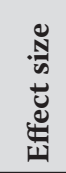 \\
\hline & & $N$ & $\mathbf{M}$ & SD & $\mathbf{F}$ & $\mathbf{F}$ & \\
\hline \multirow{5}{*}{$\begin{array}{l}\text { Others } \\
\text { centred } \\
\text { values }\end{array}$} & No work experience & 63 & $-0,08$ & 0,88 & \multirow{5}{*}{3,68} & \multirow{5}{*}{$2,66^{*}$} & \multirow{5}{*}{0,23} \\
\hline & Up to 3 years & 54 & $-0,11$ & 1,02 & & & \\
\hline & $4-6$ years & 31 & 0,42 & 0,89 & & & \\
\hline & $7-9$ years & 20 & $-0,36$ & 1,04 & & & \\
\hline & 10 and more years & 25 & 0,21 & 0,80 & & & \\
\hline \multirow{5}{*}{$\begin{array}{l}\text { Self-centred } \\
\text { values }\end{array}$} & No work experience & 63 & $-0,10$ & 0,94 & \multirow{5}{*}{3,63} & \multirow{5}{*}{$3,84^{* * *}$} & \multirow{5}{*}{0,27} \\
\hline & Up to 3 years & 54 & 0,11 & 1,06 & & & \\
\hline & $4-6$ years & 31 & 0,51 & 1,00 & & & \\
\hline & $7-9$ years & 20 & $-0,36$ & 0,86 & & & \\
\hline & 10 and more years & 25 & $-0,33$ & 0,89 & & & \\
\hline
\end{tabular}

There are significant differences in others-centred values by years of work experience, $\mathrm{F}(4,188)=2,66, \mathrm{p}=0,03, \omega=, 23$, the effect size is large. CWWS score increases from group 7-9 years of work experience $(M=-0,36$; $S D=1,44)$, to group up to 3 years of work experience $(M=-0,11 ; S D=1,01)$, to group with no work experience $(M=-0,07 ; S D=0,88)$, to group with 10 and more years of work experience $(M=0,20 ; S D=0,80)$ to group of $4-6$ years of work experience $(\mathrm{M}=0,42 ; \mathrm{SD}=0,88)$.

LSD post hoc test reveal that means values increase and are statistically significant from group with no work experience to group with 4-6 years of work experience $(0,49,95 \% \mathrm{CI}[-0,07,0,92], \mathrm{p}=0,02)$ and from group with up to three years of work experience to group 4-6 years of work experience $(0,53,95 \%$ CI $[0,09,0,97], p=0,02)$. However, there is significant decrease of CWWS score from group 7-9 years of work experience to group 4-6 years of work experience $(-0,78,95 \% \mathrm{CI}[1,33,0,23], \mathrm{p}=0,006)$. According to these results we cannot straight forward conclude that students who have more work experience express more others-centred values, as results are quite dispersed.

The results also indicate significant differences in self-centred values by work experience, $F(4,188)=3,84, p<0,00, \omega=0,27$. The effect size is slightly larger for self-centred values than the effect size for other-centred values, however both values can be interpreted as large effect sizes. LSD post hoc test for self-centred values indicates that mean values increase and are statistically significant from group with no work experience to group with 4-6 years of work experience $(0,61,95 \% \mathrm{CI}[0,18,1,02], \mathrm{p}=0,005)$, from group with 7-9 years of work experience to group with 4-6 years of work experience $(0,86,95 \%$ CI $[0,31$, $1,41], \mathrm{p}=0,002)$ and from group 10 and more years of work experience to group $4-6$ years of work experience $(0,83,95 \%$ CI $[0,31,1,34], \mathrm{p}=0,002)$. 


\section{Discussion}

\subsection{Descriptive statistics for other-centred and self-centred values}

The results for descriptive statistics indicate that the three most important values for the students are related to teaching practice with children/benevolence in education ${ }^{24}$ (e.g. In working with children is very important to deal equally with everyone (...); It is important to teach children how to be honest and responsible; To care for those who need help is important to me (...), I should teach children about that). The next most important values are related to more global aspects of other-centred values/universalism and security (e.g. to promote righteousness in society, to take care of the people and to feel devoted to the group) and as third, in the descending order according to mean values, are values related to interactions and communication quality/security, conformity (e.g. It is important to listen to the people who are different from me. Even if I disagree, I still want to understand them; It is important to have good relationships with school mates and co-workers and to collaborate with the local community). In the research ECE teachers as participants chose most important positive values which were care as involving well-being of others, warmth, comfort, helpfulness and friendship and respect as involving good communications, thinking about how to treat others, seeing others point of view, understanding differences etc. which is similar content as in most important other-centred values of our research. ${ }^{25}$

In the self-centred values the means of values are more dispersed. Most important self-centred values are related to professional self-image/professional achievement and are about to get respect of others (parents and children), to get job promotions, to be successful and that others would recognize their abilities. Second most important are values related to different activities for selfwellbeing and fun/hedonism (which usually take place outside of professional environment), like to be active in sport, to experience many new things, to seek adventures, take risks and have an exciting life. The least important among selfcentred values is to be rich and have a lot of money and expensive things/power, which maybe indicate that nevertheless students of early childhood education do not value material things very high, which was also confirmed 2016 by the study of Petrova. ${ }^{26}$

\footnotetext{
${ }^{24}$ Schwartz et al., Personality process..., 667-668.

${ }^{25}$ Ingibjorg SIRGUDARDOTTIR, Johana EINARSDOTTIR, An Action research study in preschool: Developing consensus about values and values education, International Journal of Early Childhood, 48 (2016) 2, 179-181.

${ }^{26}$ Petrova, Religious identity and value systems..., 1120-1122.
} 


\subsection{Differences in Values by Age}

In differences by age, results indicate differences in other-centred values, with large size effect. The increase of other-centred values by age groups in not straight linear, however, we can conclude, that students who have 30 years or more, express higher level of other-centred values than younger students. Significant increase is from age group 18-23 to age group 30-35 years. Other research studies indicate that younger students place more importance on status and freedom values than older groups ${ }^{27}$ and that in older students internal, altruistic factors become more dominant. ${ }^{28}$ Our results might confirm the thesis, that generational differences in values exists, especially regarding greater increase of other centred-values, which include altruism, understanding of others, care for others, collaboration and slightly smaller decrease of self-centred values compared to increase of other-centred values.

\subsection{Differences in Values by Years of Study}

Differences in values by years of study are significant on other-centred values, the effect size is large. The highest score in other-centred values is expressed by $4^{\text {th }}$ year students. Although scores do not increase straight linear by years of study, we may conclude that students who study longer and gain more knowledge express higher other-centred values, which might confirm the thesis, that learning and knowledge have influence on values and preconceptions $^{29}$, which should be rebuild during their education as they gain new knowledge about children and teaching. ${ }^{30}$ It seems that study process and other professional training shapes the values. ${ }^{31}$

\subsection{Differences in Values by Student Employment Status}

In Slovenia students who study full-time have status of the student, which by the state legislation exclude employment, so this group of students is not employed. Students who study part-time can be unemployed or can be employed. Usually, their employment is in the educational sector (kindergarten) but might be also elsewhere. Our results confirm the thesis of other research-

\footnotetext{
${ }^{27}$ Lucy CENNAMO, Dianne GARDNER, Generational differences in work values, outcomes and person-organisation values fit, Journal of Managerial Psychology, 23 (2008) 8, 891-906.

${ }^{28}$ Sahin-Firat, NECLA, Pre-service teachers personal values orientations and attitudes towards teaching profession in Turkey, Educational research and Review, 11 (2016) 20, 1944-1955.

${ }^{29}$ Korthagen, In search of the essence..., 80.

${ }^{30}$ Giovacco-Johnson, Applied ethics..., 449, 453-455.

${ }^{31}$ Necla, Pre-service teachers'..., 1944-1947, 1951, 1952; Collinson, Sources of teachers'..., 323325, 328, 331; Darling-Hammond et al., Variation in teacher..., 286-290; McMullen, Education matters..., 1-3; McMullen, Effects of early childhood..., 56,
} 
ers that employment is an important condition by which values are shaped and influenced by social interaction within working environment. ${ }^{32}$

\subsection{Differences in Values by Years of Work Experience}

There are significant differences in both others-centred and self-centred values by years of work experience. Effect sizes are large. Multiple comparisons of groups for other-centred and self-centred values show that there is no simple, linear explanation of these variables. It seems the idea that other-centred values develop when the students have worked for longer is not entirely true. The test of least significant difference (LSD) shows that the group with 4-6 years of work experience expresses the highest level of self-centred values. It seems like this group really stands out in comparison to all other groups regarding values score, as differences are significant. Almost the same result is found for the other-centred values. The group with 4-6 years of work experience also expresses the highest score of other-centred values in comparison to the other groups, all the differences are significant (differences do not occur only in comparison to the group with 10 and more years of work experience).

\section{Conclusion}

These results indicate the complexity of interaction between beliefs and values held by students of preschool education and can be interpreted only in the framework of our research sample.

Results indicate that other-centred values are shaped by employment, as employed students express significantly higher scores in other-centred values than unemployed students. We may conclude the working environment might have positive or negative influences on what students have learned in their professional training and their values might be changed or influenced because of institutionally accepted beliefs, values, practices and stages of professional and moral development. ${ }^{33}$

Promising result is that differences in values by years of study are significant on other-centred values, the effect size is large, which indicates that study process shapes the values. Therefore, higher education should focus more on development of positive values for future teachers, especially because teacher

\footnotetext{
${ }^{32}$ Brown et al., Making sense..., 21-49, 69-91, 107-120; Buehl et al., The relationship..., 66-84; Gert BIESTA, How does a competent teacher become a good teacher? On judgement, wisdom and virtuosity in teaching and teacher education, in: Ruth HEILBRONN, Lorraine FOREMAN-PECK (Eds.), Philosophical perspectives on the future of teacher education, Oxford, Wiley Blackwell, 2015, 1-3; Calderhead et al., Understanding teacher education...13-15.

${ }^{33}$ Beijaard et al., Reconsidering research..., 107-115.
} 
occupation includes role-modelling for character, morality, social and emotional skills. ${ }^{34}$

Important conclusions of this study are also that students in our cohort who are older, study longer or are employed, express higher scores in other-centred values. Scores in self-centred values remain more stable and differences by various conditions do not occur. From the perspective of development of positive values, it is better that study process takes more that only three years, that student should be included in the internship as much as possible so they would have enough time and opportunities to develop and rebuild appropriate values and beliefs to be fully qualified teachers, capable of teaching and rolemodelling positive values.

\footnotetext{
${ }^{34}$ Dahlberg et al., Ethics and politics in early childhood..., 86-90. Sigurdardottir et al., Preschool teachers communicating values..., 180, 181. Beyer, The moral contours of teacher education..., 245, 246, 250.
} 


\section{Marta Licardo* \\ Kako posebni uvjeti oblikuju vrijednosti kod studenata dodiplomskih studija predškolskog odgoja u Sloveniji? \\ Sažetak}

Svrha je studije ispitati vrijednosti kod studenata predškolskog odgoja i utvrditi koje su razlike u vrijednostima kod studenata u specifičnim socijalnim uvjetima. Vrijednosti kod dodiplomskih studenata koji studiraju predškolski odgoj vrlo su važne za profesionalni razvoj i praksu. Također je svrha studije utvrditi mijenjaju li se kod studenata vrijednosti tijekom studijskog programa; koje su vrijednosti studentima važnije; i koje su razlike u vrijednostima kod studenata s obzirom na vrstu studija (redoviti/izvanredni), godinu studija, starost, radno iskustvo i radno mjesto. Rezultati pokazuju da zaposleni studenti daju veću važnost od nezaposlenih studenata vrijednostima usmjerenim prema drugima nego vrijednostima usmjerenima na sebe; stariji studenti više prihvaćaju vrijednosti usmjerene prema drugima od mlađih studenata, dok u vrijednostima koje se usredotočuju na sebe nisu zabilježene razlike s obzirom na dob ispitanika. Studenti koji imaju više radnog iskustva i koji studiraju dulje više prihvaćaju vrijednosti usmjerene prema drugima, dok se u vrijednostima usmjerenim prema sebi ne uočavaju razlike po godinama studija. Ovi rezultati otkrivaju važne promjene u hijerarhiji vrijednosti povezanih s izmjerenim varijablama i u međuodnosu različitih uvjeta.

Ključne riječi: dob, socijalni uvjeti, studenti predškolskog odgoja, visoko obrazovanje, vrijednosti.

(na hrv. prev. Vlatka Horvat)

\footnotetext{
* Doc. dr. Marta Licardo, Sveučilište u Mariboru, Pedagoški fakultet, Koroška cesta 160, 2000 Maribor; e-mail: marta.licardo@um.si.
} 